\title{
Porównawcze studium doświadczania nudy w nauce języków drugiego i trzeciego
}

\author{
A comparative study of the experience of boredom in L2 and L3 acquisition
}

\section{Joanna ZAWODNIAK}

Uniwersytet Zielonogórski/ University of Zielona Góra

E-mail: j.zawodniak@in.uz.zgora.pl,

\section{Mariusz KRUK}

Uniwersytet Zielonogórski/ University of Zielona Góra

E-mail: mkruk@uz.zgora.pl,

\begin{abstract}
This paper focuses on examining the differences between boredom as experienced in learning the L2 and the L3. Its first part provides a theoretical background including the definition, causes of boredom and an overview of research findings, whereas the second part approaches boredom from an empirical perspective and as such it is devoted to the discussion of the results obtained from a mixed methods study conducted by the present authors on four university students of English. The collected data enabled the authors to identify the factors responsible for experiencing boredom in these two distinct language learning contexts.
\end{abstract}

Keywords: boredom in the L2; L2 and L3; factors responsible for experiencing boredom

\section{Wstęp}

Proces nauki języka obcego jest uwarunkowany współdziałaniem szeregu zmiennych ucznia, które w przeważającej części były i wciąż są przedmiotem licznych badań (np. lęk językowy, motywacja, strategie uczenia się) (Z. Dörnyei/ I. Ottó 1998, M. Pawlak 2011). Zmienną, która do tej pory doczekała się jedynie kilku opracowań empirycznych w obszarze glottodydaktyki jest nuda. ${ }^{1}$ Wiąże się to z powszechnym niedocenianiem wpływu nudy na proces uczenia się, wynikającym z niesłusznego postrzegania tej zmiennej jako objawu lenistwa uczniów, a także z faktu, iż bywa ona kojarzona z lękiem i/ lub czynnikami osobowościowymi uczących się (G.L. Macklem 2015). Tymczasem nuda jest jedną z najczęściej doświadczanych w środowisku szkolnym emocji, która może zdezorganizować i utrudnić proces uczenia się (R. Pekrun i in. 2010), co sprawia, że zagadnienie to zasługuje na większą uwagę zarówno badaczy, jak i nauczycieli. Celem niniejszego artykułu jest zbadanie różnic w doświadczaniu

\footnotetext{
${ }^{1}$ Konstrukt nudy został starannie opisany i zbadany na gruncie innych dyscyplin, takich jak psychologia, psychologia wychowawcza czy edukacja (K.E. Chapman 2013).
} 
nudy w opanowywaniu drugiego i trzeciego języka obcego. Część pierwsza poświęcona jest charakterystyce teoretycznych modeli przyczyn nudy i przeglądowi dotyczących jej badań w odniesieniu do klasy językowej. W części drugiej autorzy omawiają wyniki hybrydowego badania przeprowadzonego na czterech studentach filologii angielskiej. Poproszono ich o wypełnienie ankiety składającej się z tabel samooceny poziomu nudy, a także udzielenie odpowiedzi na pytania zachęcające do refleksji nad doświadczeniem nudy podczas nauki obu języków. Zebrane dane umożliwiły wskazanie czynników odpowiedzialnych za odczuwanie nudy w tych dwóch odrębnych sytuacjach uczenia się.

\section{Przegląd literatury}

\subsection{Modele przyczyn nudy}

Nudę określa się jako negatywny stan emocjonalny, negatywną emocję bądź negatywne doświadczenie psychiczne (S.A. Fahlman 2009) odczuwane, gdy jednostka postrzega otaczającą rzeczywistość jako mało interesującą lub zubożałą (Y.K. Goldberg $\mathrm{i}$ in. 2011). Człowiek doświadczający nudy nie jest w stanie zająć się niczym zajmującym bądź nie potrafi czerpać przyjemności z czynności pozytywnie odbieranej przez inne osoby, co sprawia, że fenomen nudy można skojarzyć $\mathrm{z}$ anhedonią (G.L. Macklem 2015).

Doświadczenie nudy uwarunkowane jest oddziaływaniem i współdziałaniem różnych czynników omówionych poniżej w obrębie kilku modeli wskazujących na przyczyny tego zjawiska. Modele te uświadamiają wagę i złożoność problemu, a tym samym zasadność jego operacjonalizacji.

- Model niedoboru bodźców (R.W. Larson/ M.H. Richards 1991) dotyczy sytuacji, gdy uczącym się nie stawia się ambitnych zadań, które zainteresowałyby ich i pobudziły do aktywności poznawczej. ${ }^{2}$ Mowa tu o zajęciach, podczas których dochodzi jedynie do stymulacji subliminalnej, która wiąże się z uczestniczeniem $\mathrm{w}$ czynnościach $\mathrm{w}$ dużej mierze powtarzalnych, a przez to przewidywalnych i bardziej skłaniających jednostki do zachowań rutynowych niż do uczenia się przez odkrywanie.

- Model wymuszonego nakładu pracy (A.B. Hill/ R.E. Perkins 1985) wskazuje, że doświadczenie nudy może być spowodowane narzuceniem przez nauczyciela zadań odbieranych przez uczących się jako monotonne bądź zbyt skomplikowane, co może prowadzić do odczuwania przez nich lęku i frustracji. Tym samym, nauczyciel przejmuje rolę kontrolera pracy ucznia, znacząco ograniczając możliwości rozwoju jego autonomii.

- Model deficytu uwagi (M.B. Harris 2000, N. LePera 2011) zakłada, że jednostki wyróżniające się skłonnością do nudy mają trudności z regulacją uwagi, a także $\mathrm{z}$ uświadomieniem sobie tego faktu. Tak więc, w modelu tym nudę definiuje się jako niezdolność do zaangażowania się i podtrzymywania

\footnotetext{
${ }^{2}$ Należy zaznaczyć, iż stopień podatności na określone bodźce może się różnić w zależności od wieku, zainteresowań, obaw, jak też systemu wartości uczących się (C.D. Fisher 1993).
} 
uwagi, co pociąga za sobą spadek zainteresowania i motywacji, czemu z kolei towarzyszy poczucie bezcelowości wykonywanej czynności (J.A. Cheyne/ J.S. Carriere/ D. Smilek 2006).

- Model kontrolująco-wartościujący (R. Pekrun i in. 2010, M. Tulis/ S.M. Fulmer 2013) podkreśla, że na odczuwanie nudy ma wpływ sposób, w jaki uczący się oceniają możliwość kontrolowania powierzonego im zadania i jego wartość. W przypadku gdy poziom kontroli, a także znaczenie tego zadania są postrzegane jako nikłe, może nastąpić poznawcza dezaktywacja uczniów i wypływająca z niej ucieczka do strategii uniku lub zachowań zaburzających przebieg lekcji.

- Model świadomego zarządzania emocjami (J.D. Eastwood i in. 2007) implikuje, że doświadczenie nudy może się wiązać z występującymi u niektórych uczących się symptomów aleksytymii, czyli nieumiejętnością rozpoznania, rozumienia i komunikowania własnych uczuć i odczuć. Jednostki, które nie są zdolne do refleksji nad swoimi emocjami i nie potrafią ani o nich rozmawiać, ani ich wyrażać, częściej niż inni pozostają podczas zajęć lekcyjnych w stanie bierności i wyobcowania.

\subsection{Przegląd badań nad nudą w klasie językowej}

Jak już wspomniano, doświadczenie nudy w nauce języka obcego jest zagadnieniem stosunkowo nowym, a przez to niewystarczająco rozpoznanym; wystarczy dodać, że studia nad tym konstruktem rozpoczęto dopiero 5 lat temu (K.E. Chapman 2013, M. Kruk 2016a, 2016b, M. Kruk/ J. Zawodniak 2017, 2018, J. Zawodniak/ M. Kruk/ J. Chumas 2017), natomiast wcześniej motyw nudy pojawiał się w badaniach jedynie incydentalnie i w sposób pośredni, tj. przy okazji omawiania innej problematyki, jak na przykład relacja między motywacją a stosowaniem materiałów autentycznych (M. Peacock 1997) czy stosunek uczniów i nauczycieli do nauczania gramatyki (G. Jean/ D. Simard 2011).

W badaniu przeprowadzonym na grupie uczących się języka niemieckiego jako obcego K.E. Chapman (2013) podjęła próbę rozpoznania czynników odpowiedzialnych za odczuwaną przez nich nudę. Wyniki wykazały, że istotną rolę w tym doświadczeniu odgrywa postawa samych uczniów oraz że wpływ nauczyciela w tym zakresie bardziej odnosi się do jego osobowości niż przygotowanych przezeń czynności lekcyjnych.

Pozostałe badania zostały przeprowadzone przez autorów tego artykułu, którzy bliżej zajęli się problematyką nudy doświadczanej w różnych kontekstach uczenia się języka. Badanie M. Kruka (2016a) przeprowadzone wśród uczniów szkoły ponadgimnazjalnej wykazało, że poziom odczuwanej przez nich nudy zmieniał się zarówno z lekcji na lekcję, jak i podczas ich trwania. Wśród przyczyn nudy wyodrębniono stopień trudności poszczególnych zadań, ogólną skłonność do doświadczania nudy, a także konieczność wykonywania ćwiczeń z gramatyki. Kolejne badanie M. Kruka (2016b) poświęcone było zmianom w poziomach nudy, a także motywacji i lęku językowego, odczuwanym $\mathrm{w}$ trakcie pobytu grupy studentów filologii angielskiej w świecie wirtualnym Second Life. W wyniku badania zaobserwowano fluktuacje w 
poziomie nudy, podobnie jak w poziomie motywacji. Doświadczenie nudy zmieniało się zarówno pod wpływem widocznego u respondentów zamiaru wykorzystania możliwości stwarzanych przez SL do porozumiewania się w języku angielskim, jak i ze względu na rozczarowanie spowodowanie nie zawsze fortunnymi kontaktami z rezydentami SL, którzy nie okazywali chęci do prowadzenia dłuższych rozmów bądź zachowywali się nieżyczliwie i agresywnie. Przedmiotem badania przeprowadzonego przez M. Kruka i J. Zawodniak (2017) była ogólna podatność na nudę studentów filologii angielskiej zestawiona ze skłonnością do odczuwania jej w czasie zajęć z praktycznej nauki języka angielskiego (PNJA). Z badania wyłoniła się dodatnia korelacja pomiędzy obiema tendencjami, ponadto zaobserwowano znaczenie upływu czasu dla przyrostu podatności na nudę $\mathrm{w}$ trakcie zajęć $\mathrm{z}$ PNJA. Rozpoznano również takie czynniki oddziałujące na odczuwanie nudy, jak osoba nauczyciela i oferowane przez niego formy pracy, dysonans pomiędzy wykonywanymi czynnościami a poziomem biegłości językowej uczących się, a także powtarzalny charakter tychże czynności. W kolejnym badaniu J. Zawodniak i in. (2017) dokonali analizy opinii studentów filologii angielskiej na temat sytuacji podczas zajęć z PNJA i przedmiotów akademickich, w jakich doświadczyli szczególnego zaangażowania i/ lub zniechęcenia. Wśród czynników przyczyniających się do intensyfikacji doświadczenia nudy należy wymienić brak informacji zwrotnych, konieczność przygotowywania przez studentów prezentacji na z góry narzucone, nieinteresujące ich tematy, wykonywanie zadań niedopasowanych do poziomu ich kompetencji językowych czy nieumiejętność wypracowania sobie własnych celów uczenia się. Wreszcie, M. Kruk i J. Zawodniak (2018) zajęli się zbadaniem sposobów okazywania nudy, a także radzenia sobie z tym problemem. Otrzymane wyniki ujawniły między innymi, że respondenci (ponownie studenci filologii angielskiej) bardziej aktywnie poszukiwali możliwości przezwyciężenia doświadczenia nudy w sytuacjach pozaszkolnych niż szkolnych.

\section{Projekt badawczy}

\subsection{Cel i pytania badawcze}

Celem projektu badawczego było bliższe przyjrzenie się zmianom w doświadczaniu nudy w uczeniu się języka angielskiego i drugiego języka obcego podczas zajęć z tych języków odbywających się w pierwszych trzech semestrach studiów oraz wskazanie czynników odpowiedzialnych za odczuwanie nudy w tych dwóch odrębnych sytuacjach uczenia się. Autorzy badania poszukiwali odpowiedzi na następujące pytania badawcze:

1. Jak zmienia się poziom nudy uczestników podczas uczenia się języka drugiego i trzeciego w trakcie każdego semestru i z semestru na semestr?

2. Jakie czynniki są odpowiedzialne za odczuwanie nudy w tych dwóch odrębnych sytuacjach uczenia się języków obcych?

Warto tu odnotować, że na użytek przedstawionego poniżej badania nudę zdefiniowano jako subiektywny stan braku zaangażowania w proponowane przez nauczyciela czynności, który może być odczuwany z różnym nasileniem, w zależności od 
indywidualnych predyspozycji i preferencji ucznia, jak też od czynników sytuacyjnych.

\subsection{Uczestnicy}

Zaprezentowane wyniki opracowane zostały na podstawie danych zebranych od czterech osób, które wyraziły chęć wypełnienia ankiety dotyczącej doświadczania nudy w procesie uczenia się języka angielskiego i kolejnego języka obcego. Dokładniej rzecz ujmując, uczestnikami badania byli studentki i studenci (tj. dwie kobiety i dwóch mężczyzn) drugiego roku filologii angielskiej w wieku od 20 do 22 lat (średnia 20,75). Troje uczestników badania dodatkowo uczęszczało na zajęcia z języka niemieckiego, a jeden z języka francuskiego. Ich średnia długość nauki języka angielskiego wyniosła 11,25 lat, zaś niemieckiego i francuskiego 7 lat. Średnia ocen uzyskanych z egzaminu z praktycznej nauki języka angielskiego wyniosła 3,25 , natomiast średnia ocen z języków niemieckiego/francuskiego otrzymanych przez uczestników badania w ostatnim semestrze równa była 3.38 . W przypadku samooceny poziomu zaawansowania języków ich średnia wartość wyniosła: 3,25 dla języka angielskiego i 2,25 dla języków niemieckiego i francuskiego. Szczegółowe informacje dotyczące uczestników badania zawiera tabela 1 .

\begin{tabular}{|c|c|c|c|c|c|c|}
\hline & 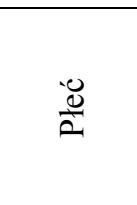 & $\frac{y}{3}$ & 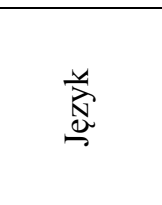 & 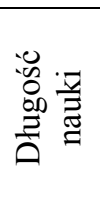 & 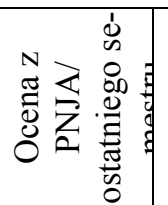 & 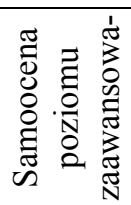 \\
\hline \multirow[t]{2}{*}{$\begin{array}{l}\mathrm{S} \\
1 \\
\end{array}$} & kobieta & 20 & angielski & 13 & 3 & 3 \\
\hline & & & niemiecki & 7 & 3 & 2 \\
\hline \multirow[t]{2}{*}{$\begin{array}{l}\mathrm{S} \\
2\end{array}$} & $\begin{array}{l}\text { mężczy- } \\
\text { zna }\end{array}$ & 20 & angielski & 12 & 3 & 3 \\
\hline & & & niemiecki & 7 & 3 & 2 \\
\hline \multirow[t]{2}{*}{$\begin{array}{l}\mathrm{S} \\
3 \\
\end{array}$} & kobieta & 22 & angielski & 14 & 4 & 3 \\
\hline & & & niemiecki & 7 & 3 & 2 \\
\hline \multirow[t]{2}{*}{$\begin{array}{l}\mathrm{S} \\
4 \\
\end{array}$} & $\begin{array}{c}\text { mężczy- } \\
\text { zna }\end{array}$ & 21 & angielski & 6 & 3 & 4 \\
\hline & & & francuski & 4 & 4.5 & 3 \\
\hline
\end{tabular}

Tab. 1. Uczestnicy badania.

\subsection{Pobór i analiza danych}

Dane zebrano za pomocą ankiety składającej się z dwóch części. Część pierwsza ankiety dotyczyła retrospektywnego studium nudy w nauce języka angielskiego, natomiast część druga związana była z retrospektywnym studium nudy w uczeniu się kolejnego języka obcego. W każdej części ankiety uczestnicy badania poproszeni zostali o opis procesu doświadczania nudy w trakcie uczenia się języków obcych podczas 
zajęć na uczelni w okresie trzech minionych semestrów z uwzględnieniem trzech różnych punktów w czasie (tj. na początku, w środku i na końcu każdego semestru). W tym celu poproszeni oni zostali o rozważenie odpowiedzi na przykładowe pytania: (1) Kto powodował nudę (nauczyciele, rówieśnicy itp.)? (2) Co powodowało nudę (zadania językowe, materiały do nauki języka obcego, metody nauczania, stosowane techniki, itp.)? (3) W jakich sytuacjach najczęściej doświadczał(a) Pani/Pan nudy? Następnie zadaniem uczestników badania było oszacowanie poziomu doświadczenia nudy podczas uczenia się obu języków obcych w trakcie każdego semestru. W tym celu wykorzystano skalę od 1 (brak nudy) do 7 (najwyższy poziom nudy). Na początku każdej części ankiety respondenci poproszeni zostali również o podanie długości nauki każdego z języków obcych, oceny z egzaminu PNJA i oceny, jaką otrzymali w ostatnim semestrze $\mathrm{z}$ kolejnego języka obcego (odpowiednio, języka angielskiego i języka niemieckiego/francuskiego) oraz samooceny poziomu zaawansowania rzeczonych języków.

Zebrane dane poddane zostały analizie ilościowej i jakościowej. W przypadku tej pierwszej, analiza dotyczyła danych pochodzących z początkowych części ankiety (tj. danych związanych z uczestnikami badania) oraz samooceny poziomu odczuwania nudy w każdym semestrze, dla których wyliczono średnie. Natomiast analiza jakościowa została przeprowadzona $\mathrm{w}$ odniesieniu do danych pochodzących $\mathrm{z}$ opisów doświadczania nudy, w których poszukiwano informacji związanych z czynnikami odpowiedzialnymi za wystąpienie nudy w dwóch odrębnych sytuacjach uczenia się, tj. podczas nauki języków angielskiego i niemieckiego/francuskiego.

\section{Wyniki badania}

\section{S1}

Analiza danych ujawniła, że doświadczenie nudy w uczeniu się języka angielskiego S1 wzrastało (od poziomu minimalnego) z początkiem każdego semestru osiągając najwyższe wartości z końcem każdego semestru (maksymalne wartości odnotowano w przypadku semestru drugiego i trzeciego) (wykres 1). Średnia zmian w odczuwaniu nudy u S1 z semestru na semestr była najniższa w semestrze pierwszym $(3,67)$, a najwyższa w semestrze drugim (4.67). Analiza wypowiedzi zawartych $w$ ankiecie pokazała, że powodem rosnącego natężenia odczuwania nudy była monotonia zajęć i wykonywanych podczas nich zadań oraz ich schematyczność, duża ilość materiału (semestr 3), poczucie braku postępów w nauce (semestr 2) i doświadczenie wolno płynącego czasu podczas zajęć (semestr 3), na przykład:

- coraz większa monotonia dotycząca przebiegu zajęć i wykonywanych zadań (semestr 1, środek);

- znudzenie zajęciami i oczekiwanie na ich koniec (semestr 1, koniec);

- $\quad$ poczucie, że nie niczego się nie uczę (semestr 2, środek);

- spadek chęci do nauki przez dużą ilość materiału, monotonia, znudzenie na zajęciach (semestr 3, środek);

- dłużące się zajęcia i nuda na lekcjach. (semestr 3, koniec). 


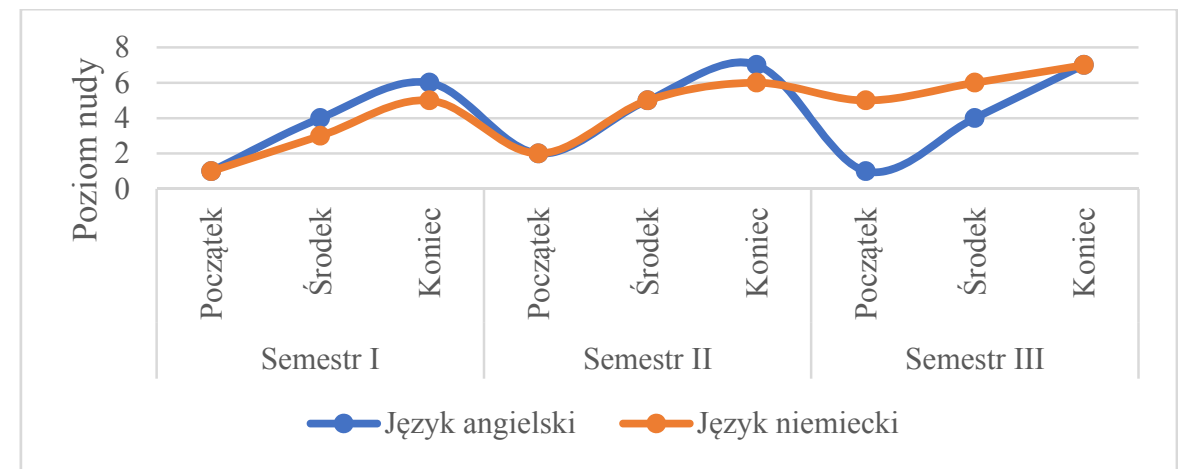

Wykres 1. Zmiany w poziomie nudy w uczeniu się języka angielskiego i języka niemieckiego u S1.

Jak widać na wykresie 1, w przypadku języka niemieckiego doświadczenie nudy u S1 zwiększało się stopniowo w trakcie każdego semestru (tj. było ono najniższe w ich początkowej części, a największe w ich końcowej) oraz z semestru na semestr (średnio: semestr pierwszy 3 punkty, semestr drugi 4,33, semestr trzeci 6 punktów). Rzeczony wzrost uczucia nudy podczas zajęć spowodowany był ich monotonią, wykonywaniem podobnych zadań i towarzyszącym S1 przeświadczeniu, że nie uczy się „niczego nowego i ciekawego”. Oprócz wymienionych czynników wywołujących nudę u S1, dodatkowo w semestrze trzecim nudę potęgowały: trudniejszy materiał, wymagający nauczyciel oraz „poczucie niewiedzy z języka niemieckiego”, na przykład:

- $\quad$ spadek chęci do nauki, odczucie monotonii na zajęciach (semestr 1, koniec);

- coraz więcej materiału, powtarzające się schematy lekcji, znudzenie przedmiotem przez wykonywanie podobnych zadań na zajęciach i poczucie, że nie uczymy się niczego nowego i ciekawego (semestr 2, środek);

- (...) poczucie, że robi się w kółko to samo; brak czegoś nowego (semestr 3, środek).

\section{S2}

Tak jak w przypadku S1, doświadczenie uczucia nudy w uczeniu się języka angielskiego u S2 zwiększało się w trakcie trwania każdego semestru oraz z semestru na semestr (wykres 2). Należy jednak zauważyć, że u S2 było ono generalnie niższe w semestrze pierwszym ( 3 punkty) niż w semestrach drugim i trzecim (odpowiednio: 4,67 i 5 punktów). Analiza wypowiedzi S2 dotyczących poszczególnych semestrów pokazała, że czynnikami wywołującymi nudę w semestrze pierwszym było „rozczarowanie zajęciami”, brak efektów w nauce, przeświadczenie S2, że „to co dzieje się na zajęciach nie wydaje się potrzebne" oraz brak zainteresowania tematami zajęć. $\mathrm{W}$ trakcie drugiego i trzeciego semestru doświadczenie nudy u S2 zwiększały także nieciekawe tematy zajęć, które skutkowały brakiem chęci do pracy, zmęczeniem i powracającymi myślami związanymi z opuszczaniem zajęć z wymienionych wcześniej powodów, na przykład:

- brak chęci przychodzenia na zajęcia i nuda na każdych zajęciach ponieważ tematy były nieciekawe (semestr 2 , środek);

- poczucie braku sensu zajęć i totalna nuda wywołująca zmęczenie (semestr 3, koniec). 


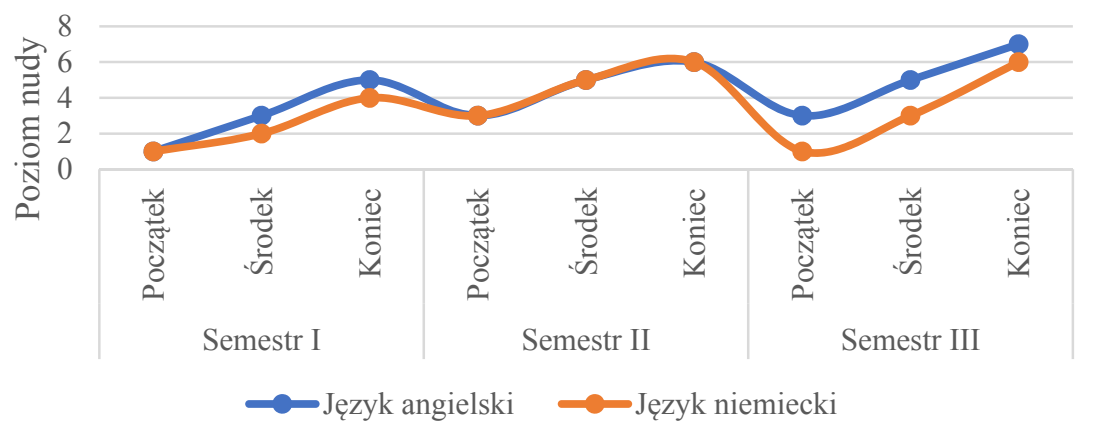

Wykres 2. Zmiany w poziomie nudy w uczeniu się języka angielskiego i języka niemieckiego u S2.

Jeśli chodzi o doświadczenie uczucia nudy podczas nauki języka niemieckiego, to podobnie jak w przypadku nauki języka angielskiego, było ono najniższe na początku każdego semestru i zwiększało się w trakcie ich trwania (wykres 2). Należy jednak zauważyć, że w przypadku języka niemieckiego najniższy średni poziom nudy odnotowano w semestrze pierwszym $(2,33)$, a największy średni jej poziom wystąpił w semestrze drugim $(4,67)$. Analiza wypowiedzi S2 pokazała, że głównymi czynnikami powodującymi nudę od początku semestru pierwszego do końca semestru trzeciego okazały się: bardzo szybkie tempo realizowanego materiału, wymagający nauczyciel, niedostateczna znajomość języka niemieckiego oraz narastające zaległości w jego nauce, na przykład:

- nuda na zajęciach ponieważ nie rozumie się języka i nie wraca się do poprzednich rzeczy co wywołuje bezradność i brak chęci do pracy. Nauczyciel za dużo wymaga (semestr 1, koniec);

- nuda i poczucie bezradności ponieważ jest się za bardzo w tyle z materiałem przerobionym na zajęciach; nauczyciel za dużo wymaga (semestr 2, koniec);

- poczucie bezradności i nudy na zajęciach z powodu zbliżającego się egzaminu który i tak będzie porażką; nuda na zajęciach ponieważ straciło się nadzieję, a zajęcia są prowadzone monotonnie; za dużo wymaga nauczyciel (semestr 3, koniec).

\section{S3}

Jak widać na wykresie 3, poziom odczuwania nudy w uczeniu się języka angielskiego u S3 zmieniał się w trakcie każdego semestru i z semestru na semestr. W semestrze pierwszym doświadczenie nudy było największe w jego początkowej fazie, $w$ drugim w jego części środkowej i końcowej, natomiast w trzecim semestrze uczucie nudy utrzymywało się na niewysokim i niezmiennym poziomie. Jeśli chodzi o średnią zmian w odczuwania nudy z semestru na semestr, to była ona najwyższa w semestrze pierwszym (4.33 punktu), a najniższa w semestrze trzecim (3 punkty). Analiza wypowiedzi S3 ujawniła, że najczęstszymi przyczynami odczuwania nudy były niski poziom językowy zajęć, nieciekawe tematy i zadania oraz powtarzanie wcześniej omawianych zagadnień. S3 był także znudzony (nie)uczestniczeniem w zajęciach, pod- 
czas których, zdaniem uczestniczki badania, „wykładowcy znajdowali wśród studentów ulubieńców i to głównie im poświęcali czas w trakcie zajęć na np. dyskusje, w międzyczasie pozostali studenci siedzieli praktycznie nic nie robiąc." Poniższe wypowiedzi stanowią ilustrację pozostałych przyczyn odczuwania nudy przez S3:

- Poruszaliśmy tematy podstawowe, które od dawna miałam opanowane, przez co zajęcia wydawały mi się trochę nudne (...) (semestr 1, początek).

- Na niektórych zajęciach wykładowcy nie realizowali tematów, które interesowały studentów (np. teksty z czytania na nudny temat), co nie skłaniało do chęci podjęcia dyskusji, a nawet dogłębnego zapoznania się z ich treścią (semestr 1, środek).

- W tym semestrze duża część uwagi była skupiona na egzaminach z PNJA. W pewnym momencie stało się to nudne, gdyż na części przedmiotów na każdych kolejnych zajęciach rozmawialiśmy o tym samym. (semestr 2, koniec)

- Znowu pojawił się problem złego doboru materiału, co powodowało brak zainteresowania ze strony studentów (semestr 3, środek).

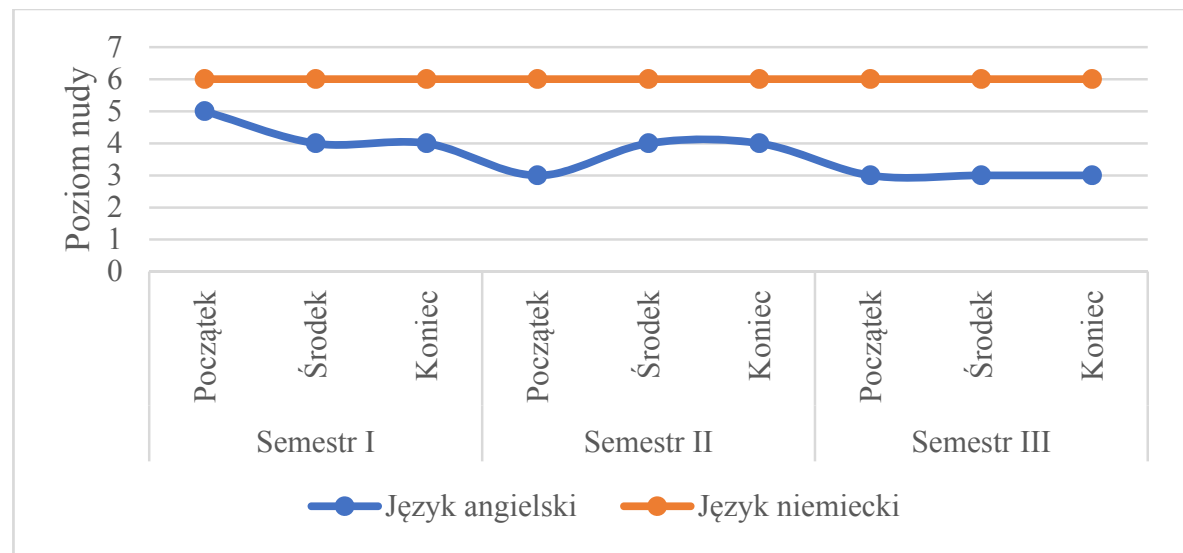

Wykres 3. Zmiany w poziomie nudy w uczeniu się języka angielskiego i języka niemieckiego u S3.

Doświadczenie nudy w przypadku uczenia się języka niemieckiego u S3 utrzymywało się na stałym i wysokim poziomie od początku semestru pierwszego do końca semestru trzeciego (wykres 3). Powodem rzeczonego wysokiego i niezmiennego poziomu nudy były, zdaniem uczestniczki badania, ,niechęć do nauki języka niemieckiego", powtarzanie materiału ze szkoły ponadgimnazjalnej i poprzednich semestrów, wykonywanie podobnych zadań podczas zajęć i braki w znajomości tegoż języka, na przykład:

- na zajęciach były omawiane bardzo podstawowe rzeczy, to samo co w liceum. (semestr 1, środek);

- brak zainteresowania językiem nieustannie wywołuje u mnie nudę. (semestr 2, środek);

- w pewnym momencie przestałam rozumieć, co się dzieje na zajęciach i to spowodowało jeszcze większą nudę. (semestr 2, koniec); 
- nadal brak ciekawych zajęć. Wszystko powtarza się z poprzednich semestrów. (semestr 3, środek).

\section{S4}

W nauce języka angielskiego S4 towarzyszyło maksymalne (7 w skali od 1 do 7) i stałe uczucie nudy od początku nauki rzeczonego języka na uniwersytecie ( $\mathrm{tj}$. od semestru pierwszego) do końca semestru drugiego, po czym nastąpił nagły spadek (do 3 punktów) w jej doświadczaniu wraz z rozpoczęciem semestru trzeciego, który utrzymywał się na stałym i niezmiennym poziomie do jego zakończenia (wykres 4). Nudę w trakcie pierwszego roku studiów powodowały: nieangażujący się wykładowcy, mało interesujące i łatwe zadania językowe, przestarzałe materiały dydaktyczne i niezmienność prowadzenia zajęć. Na zmniejszenie doświadczania nudy w semestrze trzecim miały zaś wpływ zmiana nauczycieli prowadzących zajęcia z praktycznej nauki języka angielskiego, ich zaangażowanie, zróżnicowanie i wyższy poziom zadań językowych, na przykład:

- nuda spowodowana była brakiem zaangażowania wykładowcy. W większości przypadków tematyka zadań była mało interesująca. W sytuacjach kiedy trzeba było robić kilka stron zadań, a wykładowca pod koniec tylko podawał odpowiedzi. (semestr 1, początek);

- brak zmian jeżeli chodzi o poziom zaangażowania. Materiały były mało interesujące (wręcz przestarzałe - kasety na słuchaniu - co według mnie abstrakcja. Nie dało się nic zrozumieć). (semestr 2, początek);

- zmiana wykładowców wpłynęła bardzo pozytywnie na naszą grupę. Byli bardzo pomocni i dużo można było wynieść z zajęć. Zadania były bardziej nawiązujące do naszych zainteresowań oraz ich poziom był adekwatny do naszego (...). Na zajęciach panowała też bardziej luźna, życzliwa oraz przyjazna atmosfera - wykładowca był zaangażowany, co wpłynęło na naszą pracę. (semestr 3, początek).

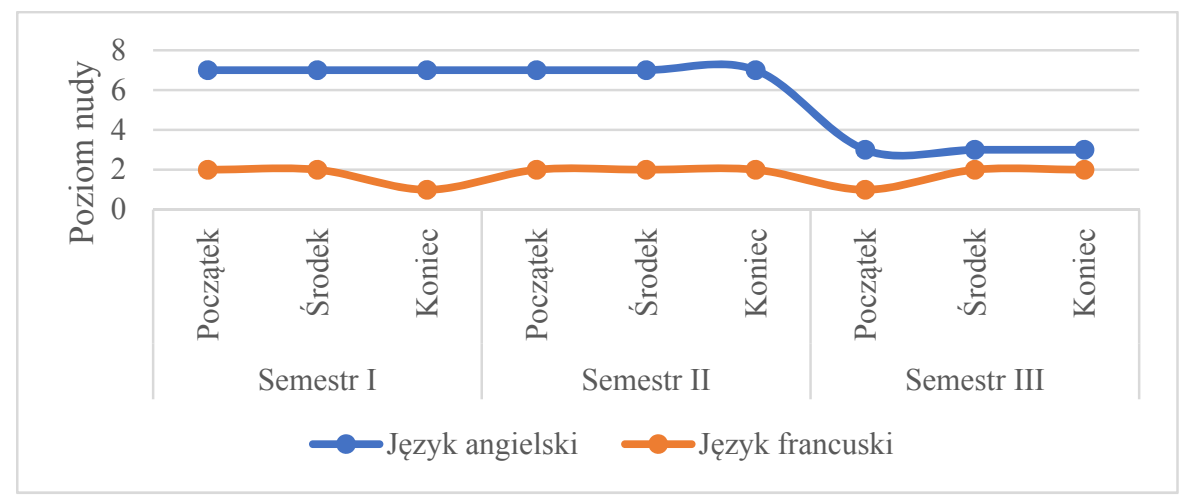

Wykres. 4. Zmiany w poziomie nudy w uczeniu się języka angielskiego i języka francuskiego u S4.

W przypadku języka francuskiego, poziom nudy zdeklarowany przez S4 był bardzo niski (tj. najwyższe jej natężenie nie przekraczało 2 punktów w skali od 1 do 7) przez cały badany okres. Należy także dodać, że nuda w ogóle nie pojawiła się w końcowej części semestru pierwszego i początkowej części semestru trzeciego (wykres 
4). Zdaniem S4 doświadczanie nudy było znikome, gdyż: „Zajęcia prowadzone były w sposób ciekawy, wykładowca starał się zachęcić i zainteresować językiem. Pomoc na każdym kroku - nie zostałem zostawiony na zasadzie „masz zadanie i je rób” - co było notoryczne w I i II sem. na zaj. z PNJA. Jeżeli nawet pojawiła się nuda to zazwyczaj przeglądałem podręcznik zaciekawiony co będzie dalej na zajęciach.”

\section{Dyskusja}

\subsection{Pytanie badawcze nr 1 - ilościowy pomiar danych}

Uzyskane wyniki wskazują na pewne prawidłowości w odczuwaniu nudy, które można rozpatrywać zarówno $\mathrm{w}$ kategoriach podobieństw, jak i różnic $\mathrm{w}$ doświadczeniach poszczególnych respondentów.

Można zaobserwować pewne podobieństwa w kształtowaniu się poziomów nudy u S1 i S2. W obu przypadkach doświadczenie nudy w nauce języków drugiego i trzeciego było najmniej intensywne na początku każdego semestru, zaś najwyższe w jego końcowej części. Jednocześnie należy odnotować, że ogólnie poziom nudy był wyższy w odniesieniu do języka angielskiego niż niemieckiego.

Inaczej doświadczenie nudy kształtowało się w przypadku S3 i S4, u których doświadczenia nudy w nauce języków drugiego i trzeciego były rozbieżne. Otóż u S3 w przypadku języka drugiego odczuwanie nudy było najbardziej intensywne na początku semestru pierwszego, zaś najsłabsze podczas semestru trzeciego. Natomiast w nauce języka niemieckiego poziom nudy był bardzo wysoki i cechowała go stabilność w czasie wszystkich trzech semestrów. Z kolei u S4 w przypadku języka angielskiego można zauważyć stałe, maksymalnie wysokie doświadczenie nudy w trakcie semestrów pierwszego i drugiego oraz znaczący jego spadek w semestrze trzecim. Odnośnie do nauki języka francuskiego, doświadczenie nudy utrzymywało się na bardzo niskim poziomie przez cały objęty badaniem okres.

\subsection{Pytanie badawcze nr 2 - jakościowy pomiar danych}

Zmiany w poziomie nudy odczuwanej przez czworo respondentów ${ }^{3}$ podczas nauki języków drugiego i trzeciego spowodowane były szeregiem czynników, które głównie dotyczą postawy nauczyciela, sposobu prowadzenia przezeń zajęć i rodzajów wykonywanych przez studentów czynności.

Wśród źródeł nudy doświadczanej podczas uczenia się języka drugiego należy wymienić towarzyszącą zajęciom monotonię (S1, S2, S3, S4), która wynikała z powtarzalności, a przez to przewidywalności podejmowanych zadań (S1, S3, S4), niskiego stopnia ich trudności (S4), nieatrakcyjnej formy zajęć (S4) i omawiania nieciekawych tematów (S2, S3, S4), które były nieumiejętnie dobierane (S1, S3). Dłużące się zajęcia przeładowane mało interesującym materiałem obniżały zaangażowanie studentów (S1) i wywoływały znużenie, a także związane z nim obniżenie motywacji do obecności na zajęciach (S2). Zmniejszeniu poziomu nudy nie sprzyjało też

\footnotetext{
${ }^{3}$ Respondenci rekrutowali się z różnych grup, co zapewne również miało wpływ na sposób i intensywność doświadczania nudy.
} 
podporządkowanie części zajęć rutynowym przygotowaniom do egzaminu z PNJA. Kolejnym ważnym czynnikiem obniżającym chęć uczestniczenia w zajęciach było poczucie bezcelowości (S1, S2, S4), wiążące się z przekonaniem o nieprzydatności przerabianego materiału (S2), a także ze świadomości zastoju i braku postępów w nauce (S1). Warto również wspomnieć o postawie nauczyciela jako czynniku przyczyniającym się, w pewnych sytuacjach, do doświadczenia nudy, szczególnie gdy brakuje mu zaangażowania (S4) i gdy, pozbawiony obiektywizmu, nie stara się on w równym stopniu zachęcać wszystkich studentów do uczestniczenia w zajęciach. Na oddzielne, choć zwięzłe omówienie zasługuje przypadek S4, gdyż w odczuwanej przez tę osobę nudzie można wyróżnić dwa całkowicie odrębne okresy, jeden przypadający na semestry pierwszy i drugi, w którym poziom tego doświadczenia był bardzo wysoki, co zasygnalizowano w powyższej dyskusji, i drugi, dotyczący semestru trzeciego, podczas którego odczuwalność nudy wyraźnie zmalała. Ten dość gwałtowny zwrot w doświadczeniu nudy wiąże się ze zmianą nauczycieli, których zaangażowanie, umiejętność dostosowywania materiałów nauczania do poziomu biegłości językowej grupy, jak też życzliwe nastawienie do studentów pozytywnie oddziaływały na odbiór przez S4 zajęć jako sensownych i interesujących.

Za jedną z przyczyn nudy podczas nauki języka trzeciego wskazano, podobnie jak w przypadku języka drugiego, monotonię (S1, S2, S3), co się wiązało z podobnym przebiegiem zajęć, które z reguły były mało interesujące. Studenci (S1, S2), odczuwali bezsens uczenia się języka, którego nie rozumieli (S2), a przez to mieli świadomość własnej niewiedzy i niewynoszenia niczego nowego z zajęć (S1). Doświadczeniu nudy sprzyjała osoba wymagającego nauczyciela (S1, S2), który zbyt szybko realizował materiał (S2) o dużym stopniu trudności (S1), bez nawiązywania do wcześniej już omówionych zagadnień (S2). Szybkie tempo zajęć prowadziło do frustracji z powodu narastających zaległości, a zbliżający się egzamin potęgował niewiarę we własne możliwości i poczucie bezsilności (S2). Wreszcie, warto wspomnieć o relacji występującej pomiędzy stanem znudzenia a brakiem zainteresowania językiem niemieckim i ogólną niechęcią do uczenia się go (S3). Zupełnie inaczej przedstawiała się sytuacja w odniesieniu do S3, u którego poziom nudy w trakcie nauki języka francuskiego był bardzo niski. Przyczynił się do tego interesujący sposób prowadzenia zajęć i pomocny wykładowca.

Porównując doświadczenie nudy zaobserwowane u respondentów podczas nauki języków drugiego i trzeciego, można odnotować pewne wspólne przyczyny tego zjawiska, jak monotonny charakter zajęć i niewłaściwa selekcja materiału nauczania (model niedoboru bodźców), z tym że w przypadku języka drugiego dotyczy to zbyt łatwych, zaś w przypadku języka trzeciego zbyt trudnych zadań. Pozwala to wnioskować, że dobra orientacja nauczyciela w zakresie potrzeb poznawczo-językowych uczniów i umiejętne adresowanie tych potrzeb może dodatnio wpływać na poziom ich zaangażowania, a tym samym na aktywne i chętne uczestniczenie w czynnościach lekcyjnych. Nauce języków drugiego i trzeciego do pewnego stopnia towarzyszyło też poczucie bezcelowości i bezsilności wobec zadań, które nie wzbudzały zaciekawienia studentów i/ lub były przez nich postrzegane jako nieposiadające znaczenia (model kontrolująco-wartościujący), prowadząc do znużenia i negatywnego myślenia 
o zajęciach, co objawiało się wyczekiwaniem ich zakończenia lub chęcią opuszczania ich. Warto tu dodać, że zadania, które uczący się odbierają jako użyteczne są wskazywane przez badaczy (C.S. Hulleman/ J.M. Harackiewicz 2009) jako skuteczne antidotum na nudę i brak wytrwałości. Można też domniemywać, że wstępne oczekiwania i cele, z jakimi respondenci przystąpili do nauki obu języków nie zostały zrealizowane, co przypuszczalnie wiąże się z postawą nauczycieli jako kontrolerów pracy studentów, którzy dość sztywno trzymali się ram programu nauczania, z reguły nie uwzględniając ich zainteresowań (model wymuszonego nakładu pracy). Uwagę zwraca także bardziej negatywny wydźwięk komentarzy dotyczących nauki języka trzeciego (niemieckiego) niż drugiego (angielskiego). Analiza wypowiedzi respondentów jednoznacznie wskazuje na sposób prowadzenia zajęć jako główną przyczynę tego fenomenu. Dodatkowo, warto się przyjrzeć ścisłej relacji pomiędzy zdecydowanie negatywnym odbiorem zajęć a samooceną poziomu zaawansowania, która jest bardzo niska, co może sugerować, że jednostajnie przebiegające czynności działały jako czynnik bezpośrednio blokujący postępy w nauce, a pośrednio obniżający wiarę we własne umiejętności, które w istocie mogły być wyższe.

Jednocześnie należy zaznaczyć, że odpowiedzialnością za doświadczenie nudy studenci obarczali wyłącznie nauczyciela wraz z jego postawą i proponowanymi czynnościami, natomiast nie starali się spojrzeć na ten problem bardziej krytycznie, tj. również z perspektywy własnej pracy i własnych kompetencji. Taki ogląd sytuacji mógłby ich zachęcić do poszukiwania rozwiązań, co jednak zdarzało się jedynie sporadycznie, jak w przypadku lektoratu z języka francuskiego (S4). Uczęszczający na te zajęcia student $\mathrm{w}$ obliczu pojawiającej się nudy przeglądał podręcznik, aby dowiedzieć się, czego będzie się uczyć w najbliższej przyszłości. Pozostali respondenci w podobnej sytuacji przyjmowali bierną postawę rezygnacji znamionującej mimowolne podporządkowanie się biegowi zajęć. Można zatem skonstatować, że w przeciwieństwie do S4, zabrakło im kompetencji strategicznej (P. Benson 2001), która na pewno pomogłaby w podtrzymaniu uwagi i planowaniu działań zaradczych. Odwołując się do kwestii intensywności doświadczenia nudy (T. Goetz i in. 2014), można założyć, że stopień, w jakim uczący się są zaangażowani w lekcję wpływa na natężenie tej emocji, co prowadzi do wniosku, że jeżeli ogólny poziom zainteresowania jest wysoki, okazjonalnie pojawiająca się nuda jest odczuwana mniej drastycznie i nieprzyjemnie, a przez to staje się łatwiejsza do pokonania.

\section{Podsumowanie}

Omówione powyżej dane badawcze pozwalają spojrzeć na nudę jako złożony konstrukt wpisany w kontekst ekologii klasy językowej (zob. D. Larsen-Freeman 2016) i tym samym podlegający licznym, niejednokrotnie dynamicznym, bardziej lub mniej nasilonym zmianom, ale też przechodzący przez okresy względnej stabilności (zob. F. Waninge/ Z. Dörnyei/ K. de Bot 2014). Duży wpływ na przebieg tych procesów miały czynniki zarówno zewnętrzne, dotyczące osoby nauczyciela, jego zaangażowania, inwencji, warsztatu dydaktycznego i stosunku do uczących się, jak również wewnętrzne, odnoszące się do samych studentów, ich oczekiwań, kompetencji języko- 
wych i nastawienia do przedmiotu. Porównanie doświadczenia nudy w nauce języków drugiego i trzeciego wykazało, iż było ono bardziej negatywne i intensywne podczas zajęć z języka trzeciego (niemieckiego), choć przyczyny obu procesów należy uznać za zbieżne. Analiza uzyskanych wyników uprawnia do stwierdzenia, że brak zaangażowania uczących się jest konsekwencją braku zaangażowania nauczyciela, stąd też raz jeszcze warto zaakcentować znaczenie znajomości i respektowania potrzeb i zainteresowań uczniów, co powinno prowadzić do właściwego doboru materiału opartego na różnorodności bodźców poznawczo-językowych. Wreszcie, nie można zapomnieć o treningu strategicznym, który mógłby uświadomić uczącym się ich własne priorytety i możliwości ich realizacji na przekór pojawiającemu się znużeniu czy zniechęceniu. Tak więc nuda okazuje się być istotnym komponentem praktyki uczenia się języka, mogącym ją utrudniać i spowalniać, a także obniżać jej efektywność, z których to powodów konstrukt ten niewątpliwie zasługuje na dalsze dociekania empiryczne.

\section{Bibliografia}

Benson, P. (2001), Teaching and Researching Autonomy in Language Learning. Harlow, Essex.

Chapman, K.E. (2013), Boredom in the German foreign language classroom. Niepublikowana rozprawa doktorska. Madison, WI: University of Wisconsin-Madison.

Cheyne, J.A./ J.S. Carriere/ D. Smilek (2006), Absent-mindedness: Lapses of conscious awareness and everyday cognitive failures, (w:) „Consciousness and Cognition" 15 (3), 578-592.

Dörnyei, Z./ I. Ottó (1998), Motivation in action: A process model of L2 motivation, (w:) „Working Papers in Applied Linguistics” 4, 43-69.

Eastwood, J.D./ C. Cavaliere/ S.A. Fahlman/ A.E. Eastwood (2007), A desire for desires: Boredom and its relation to alexithymia, (w:) „Personality and Individual Differences" 42(6), 1035-1045.

Fahlman, S.A. (2009), Development and Validation of the Multidimensional State Boredom Scale. Niepublikowana rozprawa doktorska. Ottawa: York University.

Fisher, C.D. (1993), Boredom at work: A neglected concept, (w:) „Human Relations” 46 (3), 395-417.

Goetz, T./ A.C. Frenzel/ N.C. Hall/ U.E. Nett/ R. Pekrun/ A.A. Lipnevich (2014), An experience sampling approach, (w:) ,Motivation and Emotion” 38 (3), 401-419.

Goldberg, Y.K./ J.D. Eastwood/ J. LaGuardia/ J. Danckert (2011), Boredom: An emotional experience distinct from apathy, ahedonia, or depression, (w:) ,Journal of Social and Clinical Psychology" 30 (6), 647-666.

Harris, M.B. (2000), Correlates and characteristics of boredom proneness and boredom, (w:) ,Journal of Applied Social Psychology” 30, 576-598.

Hill, A.B./ R.E. Perkins (1985), Towards a model of boredom, (w:) „British Journal of Psychology" 76 (2), 235-240. 
Hulleman, C.S./ J.M. Harackiewicz (2009), Making education relevant: Increasing interest and performance in high school science classes, (w:) „Science” 326, 1410-1412.

Jean, G./ D. Simard (2011), Grammar teaching and learning in L2: Necessary, but boring?, (w:) „Foreign Language Annals” 44 (3), 467-494.

Kruk, M. (2016a), Investigating the changing nature of boredom in the English language classroom: Results of a study, (w:) A. Dłutek/ D. Pietrzak (red.), Nowy wymiar filologii. Płock, 252-263.

Kruk, M. (2016b), Variations in motivation, anxiety and boredom in learning English in Second Life, (w:) „The EUROCALL Review” 23 (1), 25-39.

Kruk, M./ J. Zawodniak (2017), Nuda a praktyczna nauka języka angielskiego, (w:) „Neofilolog” 49 (1), 115-131.

Kruk, M./ J. Zawodniak (2018), Boredom in practical English language classes: Insights from interview data, (w:) L. Szymański/ J. Zawodniak/ A. Łobodziec/ M. Smoluk (red.), Interdisciplinary Views on the English Language, Literature and Culture. Zielona Góra, 177-191.

Larsen-Freeman, D. (2016), Classroom-oriented research from a complex systems perspective, (w:) ,Studies in Second Language Learning and Teaching” 6 (3), 377 $-393$.

Larson, R.W./ M.H. Richards (1991), Boredom in the middle school years: Blaming schools versus blaming students, (w:) ,American Journal of Education” 99 (4), 418433.

LePera, N. (2011), Relationships between boredom proneness, mindfulness, anxiety, depression and substance use, (w:) „The New Psychology Bulletin” 8 (2), 15-25.

Macklem, G.L. (2015), Boredom in the Classroom: Addressing Student Motivation, Self-Regulation, and Engagement in Learning. New York.

Pawlak, M. (2011), Anxiety as a factor influencing the use of language learning strategies, (w:) M. Pawlak (red.), Extending the Boundaries of Research on Second Language Learning and Teaching. New York, 149-165.

Peacock, M. (1997), The effect of authentic materials on the motivation of EFL learners, (w:) "ELT Journal" 51 (2), 144-156.

Pekrun, R./ T. Goetz/ L. M. Daniels/ R.H. Stupinsky/ R.P. Perry (2010), Boredom in

achievement settings: Exploring control-value antecedents and performance outcomes of neglected emotion, (w:) ,Journal of Educational Psychology” 102 (3), 531-549.

Tulis, M./ S.M. Fulmer (2013), Students' motivational and emotional experiences and their relationship to persistence during academic challenge in mathematics and reading, (w:) „Learning and Individual Differences” 27, 35-46.

Waninge, F./ Z. Dörnyei/ K. de Bot (2014), Motivational dynamics in language learning: Change, stability, and context, (w:) ,The Modern Language Journal” 98 (3), 704-723.

Zawodniak, J./ M. Kruk/ J. Chumas (2017), Towards conceptualizing boredom as an emotion in the EFL academic context, (w:) „Konin Language Studies” 5 (4), 425441. 